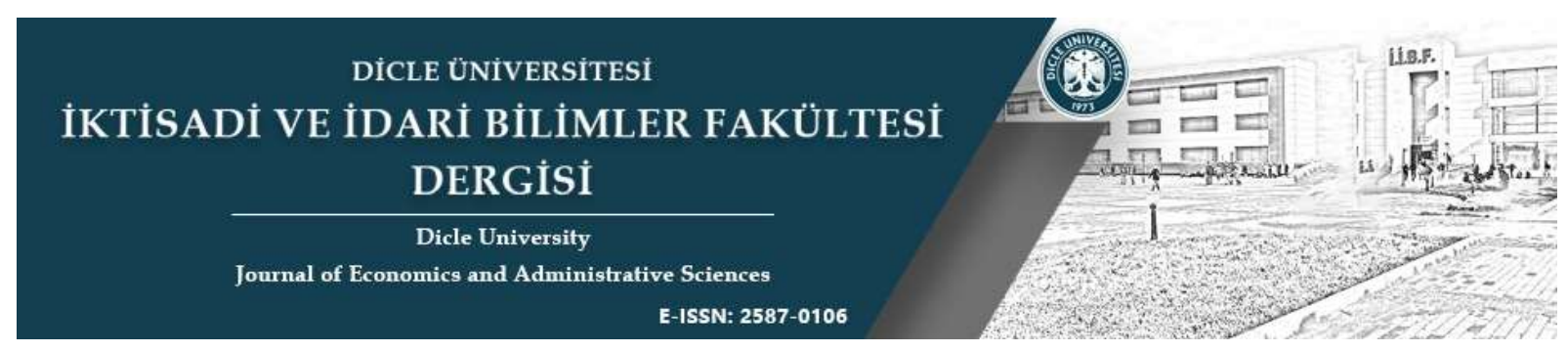

Cilt / Volume: 11, Sayı / Issue: 22, Sayfalar / Pages: 634-652

Araştırma Makalesi / Research Article

Received / Alınma: 14.07.2021

Accepted / Kabul: 21.10.2021

\title{
HEALTHCARE SCHOOL STUDENTS' WILLINGNESS TO WORK WITH THE ELDERLY: INFLUENCE OF AGEISM*
}

\author{
Rojan GÜMÜŞ1
}

\begin{abstract}
The purpose of this study is to examine the influence of ageism attitude and the associated factors such as demographics of healthcare school students on willingness to work with elderly after graduation. A cross sectional descriptive study was conducted with a total of 704 vocational healthcare school students. An online questionnaire consisting of socio-economic variables, Ageism Attitude Scale and questions related to willingness to work and live with elderly after graduation was completed by $80 \%$ of the entire study population. Data were analyzed by Normality test, Cronbach test, t-test, ANOVA and Scheffe test and Chi-square test. According to the results, willingness to work in elderly care was significantly higher in student groups having higher positive AAS scores. Elderly care willingness and AAS scores of the students showed no significant differences with regard to demographics. Only students whose mothers' educational level was higher had more positive AAS scores. AAS scores were high in all groups but willingness to work in elderly care was low. The students who have visited a nursing home showed significantly higher willingness to care for the elderly. Participants who had lived with an elderly before were less likely to live with an older adult in the future. The students showed the lowest AAS scores with regard to hiring of the elderly and $55 \%$ of them consider people at the age of 55 and over as being old. There is a positive relationship between the low ratio of ageism among young people and the tendency to work in the field of elderly care in the future. In order to encourage young people to work in this field, their concerns should be addressed and their prejudice should be eliminated. Both as part of a state policy and in terms of employment volume, students of universities' vocational healthcare schools should be encouraged to pursue a career in elderly care after their graduation.
\end{abstract}

Keywords: Healthcare School Students, Attitudes, Ageism, Elderly, Care Willingness.

Jel Codes: I18, I26, J23.

\footnotetext{
* This study was presented as an abstract in 6.Health Sciences and Management Conference on 20-22 May 2021 in Süleyman Demirel University, Isparta.

${ }^{1}$ Assoc. Prof. Dr, Dicle University,Atatürk Vocational School of Health Services, e-posta: gumusrojan@gmail.com, ORCID: 0000000181136193.
}

\section{Atıf/Citation}

Gümüş, R. (2021). Healthcare school students' willingness to work with the elderly: influence of ageism. Dicle Üniversitesi İktisadi ve İdari Bilimler Fakültesi Dergisi, 11(22), 634-652. 


\section{SAĞLIK YÜKSEKOKULU ÖĞRENCILERINİN YAŞLI AYRIMCILIĞINA KARŞI TUTUMLARININ YAŞLI BAKIMI ALANINDA ÇALIŞMA ARZUSUNA ETKİSi}

\section{$\ddot{O} z$}

Bu çalışmanın amacı sağlık yüksek okulu öğrencilerinin yaşlı ayrımcılığına karşı tutmlarının ve demografik özelliklerinin mezun olduktan sonra yaşlı bakımında çalışma arzularına olan etkisini analiz etmektir. Kesitsel ve tanımlayıcı olarak düzenlenen çalışmada 702 sağlık hizmetleri meslek yüksekokulu öğrencisi ile online olarak anket yapılmıştır. Çalışmada tüm evrenin \%80'ine ulaşılmış, öğrencilere sosyo-ekonomik özellikleri, Yaşlı Ayrımcılığı Tutum Ölçeği ve mezuniyetten sonra yaşlı bakım alanında çalışma isteğini ölçen sorular içeren bir soru formu iletilmiştir. Toplanan veriler Normallik testi, Cronbach Güvenilirlik Analizi, $t$ testi, ANOVA, Sheffe testi ve Ki-Kare testi ile analiz edilmiştir. Araştırmanın sonuçlarına göre, YATÖ ortalamaları pozitif yönden yüksek olan gruplarda mezuniyetten sonra yaşlı bakımında çalışma eğilimi istatistiksel olarak daha yüksek bulunmuştur. Mezuniyetten sonra yaşlı bakımı alanında çalışma arzusu ve YATÖ puanları açısından sosyo demografik gruplar arasında istatistiksel olarak önemli bir fark bulunmamıştır. Yalnızca anneleri daha yüksek eğitime sahip olan öğrencilerin yaşlı ayrımcılığı konusunda daha pozitif bir yaklaşım sergiledikleri görülmüştür. Tüm gruplarda pozitif YATÖ ortalamaları görülürken, yaşlı bakımında çalışma arzusu düşük bulunmuştur. Daha önce bir yaşlı bakım evi ziyaretinde bulunan öğrenciler yaşlı bakımı alanında çalışmaya daha isteklidir. Geçmiş dönemlerde bir yaşlı ile birlikte yaşamış olan öğrenciler ileride bir yaşlı ile yaşamaya mesafelidirler. Daha negatif YATÖ puanı sergileyen öğrenciler yaşlıların istihdam edilmesine sıcak bakmamakla birlikte, yarısından fazlası 55 ve yukarı yaştakileri yaşlı olarak tanımlamaktadırlar. Araştırma sonuçları göstermiştir ki genç bireyler arasında yaşlı ayrımcılığına karşı pozitif tutum ile ileride yaşlı bakımında çalışma arzusu arasında pozitif bir ilişki vardır. Gençleri bu alanda çalışmaya teşvik etmek için öncelikle kaygıları ve önyargıları giderilmelidir. Hem devlet politikası gereği hem de istihdam hacmi açısından üniversitelerin sağlık meslek yüksek okulları öğrencileri mezuniyetten sonra yaşlı bakımı alanında bir kariyer düşünmeleri için cesaretlendirilmelidirler.

Anahtar Kelimeler: Sağlık Yüksekokulu Öğrencileri, Yaşlı Ayrımcıllğı Tutumu, Yaşlı Bakımı, Çalışma Isteği.

Jel Kodları: I18, I26, J23.

\section{INTRODUCTION}

Attitude towards elderly people varies by society. Whereas in some societies the elderly is seen as individuals who are active, productive, with a continuing benefit to the society, wholly integrated into the society and not in need of care or not dependent, in others, they are viewed as a group of people from whom no social production or contribution is expected, who are regarded with love and respect, given importance and considered as people who should retreat to their corner and take a rest in their final years. As much as there are elderly people having the chance to actively continue their lives or whose health allows them to do so, there are also a lot of elderly people who are alone, left outside the society or ostracized and who struggle with health problems.

Ageism as a term was used for the first time in 1969 by the director of American National Institute on Aging, Robert Butler (Butler, 1980). The gerontologist Robert Butler described ageism as a form of discrimination against elderly people, which, like racism and gender discrimination, can become concretized and turn into action. Today, the definition made by 
Palmore is used more frequently (Palmore, 1999). Palmore defined ageism as "a term that expresses prejudice towards older people through attitudes and behaviors". It also states that ageism is one of the most common types of "discrimination", ranking third after racial and gender discrimination. Ageism is a multidimensional term that includes different attitudes, prejudices, behaviors and actions towards a person just because of their age. Therefore, when examining the data on ageism, positive and negative attitudes are considered together. Aging is perceived as a pathological condition that should be avoided if possible and is equated with disease. For this reason, ageism is also defined as the way by which the inadequacies, limitations and negative changes occurring with age are interpreted.

Ageism is a situation we come across frequently in business life, family and social life alike. In particular, we have observed from the experiences we have lived during the process of Covid19 pandemic that some segments of the society do not consider the elderly as equals and do not care about their loss. However, the elderly is the most vulnerable group in society. They are most affected in the slightest negative situation concerning public health. High number of elderly population in developed countries has led to high number of deaths in the early stages of the pandemic in these countries. In these countries where care services for elderly people are very advanced, it is observed that no matter how advanced your services are this vulnerable group has special care needs and should be given more attention than any other group in the society. No matter which group of the society we are from, care of the elderly people is one of the issues that we should focus on the most.

Although the situation of the elderly in Turkey is different, the problems today faced in developed countries with a large elderly population await us in the near future. The Turkish traditional family structure, the relatively small number of women in business life, the fact that parents have many children and the relatively low population of elderly people in our country have delayed our encounter with these problems seen in developed countries. Today, the fact that families have fewer children, women take part in work life more and the elderly population increases as a result of the improvement of both care and health conditions of our country will lead to leaving the care of the elderly to professionals and the spread of elderly care homes in our country after 10 years at the latest. Number of the elderly and its proportion to whole population has been growing in last 20 years. The projections for next years for Turkey should be investigated to understand the importance of the subject. While in 2014-2018 this ratio was $8.3 \%$, after 2019 it began to grow rapidly. Total elderly population and its ratio to whole 
population in 2023,2030 and 2060 is expected to be $10.2 \%, 12.9 \%$ and $22.6 \%$ respectively (TUIK,2021).

With the increase in our elderly population in the future, it is obvious that we will need more places that provide healthcare and residential services such as elderly care homes, nursing homes etc. in order to provide care services to our elderly people whom we have so far looked after in our homes as part of our families. With this situation, the need for trained and qualified personnel in this field will increase exponentially. There is a need for an effort to ensure healthy aging, to create elderly friendly environments, to make health services suitable for the elderly population, to provide long-term care needs and to disseminate the understanding of measurement/monitoring. For all these reasons, a professional approach is needed in the care of the elderly. Therefore, expert personnel trained in the field of elderly care are of great importance. All around the world, it has become an important state policy to train experts who will give care to the elderly. The need for personnel in work areas such as geriatric care therapists, geriatric doctors, family physicians, nurses, occupational therapists and social workers.

\section{Literature Review and Research Questions}

There are many studies that investigate ageism or attitudes towards the elderly and conduct research on individuals from all walks of life. Especially the studies conducted on university students who constitute the young population of every period and on students studying in the field of healthcare are important studies in the field of elderly care. In these studies, carried out by using scales developed by different researchers and the validity and reliability of which have been proven many times, the attitudes of young individuals towards the elderly and ageism were investigated and the relationships between these attitude scores and other variables were demonstrated (Fraboni et al.,1990; Kogan, 1961; Rosencrantz, 1969; Lasher \& Faulkender, 1993; Yılmaz \& Terzioğlu, 2011)

In the studies conducted with university students, it was stated that students generally had a positive attitude towards elderly individuals and the highest attitude scores were given against exclusion of the elderly from society. In studies conducted with nursing students which is an important occupational group in the field of healthcare, it was found that participants showed a positive attitude towards ageism (Usta et al., 2012; Demir et al., 2016; Hweidi \&Al-Obeistat, 2006; Unsar et al.,2015). The literature reveals that demographics of the students affect the ageism attitude scores. According to some researchers being female is a factor in having higher positive attitudes in terms of ageism (Bodner et al., 2012; Bergman et al., 2013; Randler et 
al.,2016; Ben-Harush et al.;Daba \& Kesen ,2015; Güven et al.,2012). On the other hand some other researches have reported non-significant results in ageism attitude scores between female and male groups (Adıbelli et al.,2013; Duyan et al., 2016; Y1lmaz\& İnce ,2017; Özdemir \& Bilgili,2016). On the other hand more negative attitudes of female nursing students were reported by Köse et al. (2015), Şahin and Erdem (2017) and Hweidi and Al-Obesitat (2006). Other previous research has found that age or studying class play a role in positive ageism scores (Daba \& Kesen ,2015; Köse et al., 2015; Hweidi \& Al-Obesitat, 2006 ; Hughes et al., 2008;Yılmaz\& Özkan, 2010; Kızılcı et al., 2013, ;Kulakçı, 2010). Soyuer et al. (2010), Bleijenberg et al. (2012), Özdemir and Bilgili (2016) and Yllmaz and İnce (2017) reported that age and study year affect ageism scores of students. On the other hand, some researchers have not found significant different results between age groups (Adibelli et al.,2013; Duyan et al., 2016). A number of studies have pointed out that residence (Duyan et al., 2016) and family type of students (Turan et al., 2016) ) play a role in higher positive ageism scores.

It is purposed in the literature that positive attitudes are reflected in health school students' care of the older adult when they graduate. In a study conducted by medical students, it has been determined that a positive attitude towards ageism is effective in the desire to work in the field of elderly care after graduation (Chua et al.,2008; Hughes et al., 2008; Wang et al., 2009). Some other research investigated ageism in special work students and have found that there is a relationship between positive ageism attitudes and willingness to work in elderly care (Daba \& Kesen, 2015). Also, there are many studies investigating the relationship between ageism attitude and willingness to work in elderly care among nursing students (Y1lmaz\& İnce ,2017; Altay \&Aydın, 2015; Karadağ et al., 2012; Y1lmaz\& Özkan, 2010). It has been found that personal contact with older people influenced students' ageism attitude (Bodner et al., 2012; Bergman et al., 2013). Living with an elderly individual at home or working with elderly are among the variables affecting students' attitudes towards ageism (Bodner et al., 2012; Bergman et al., 2013; Duyan et al., 2016 ; Erol et al., 2013; Özdemir \& Bilgili,2016; Özkaptan et al., 2012; Karadağ et al., 2012; Y1lmaz\& Özkan, 2010).

Based on the literature three research questions have been developed.:

"Do demographics of vocational health school students influence positive ageism attitude scores of them?"

"Do higher positive ageism attitude scores of vocational health school students play a role in willingness to work in elderly care in the future?" 
"Does personal contact with an older people influence positive ageism attitude scores of vocational health school students?"

While studies measuring attitudes towards ageism are common among social sciences, medicine, and nursing students, studies with associate degree students in the field of healthcare are more limited. However, in the field of health, it is the health technicians who will be in direct contact with the elderly individuals. There are no studies reporting the relationship between ageism attitude and willingness to work in elderly care among vocational health school students. For this reason, our study investigating the attitudes of students studying in nine programs of Dicle University's Atatürk Vocational School of Health Services against ageism and willingness to work in elderly care not only revealed the perspective of young people against ageism, but also benefited the decisions to be taken in health management and planning in the field of education.

This study aims to determine the attitudes of students in different programs in Dicle University's Atatürk Vocational School of Health Services towards ageism, and the role of factors such as age, gender, program and class, socio-economic status of the family, family type, education and working status of parents on AAS. Furthermore, it is aimed to demonstrate the role of personal contact with an elderly before on the attitude towards ageism and. Also willingness to work with the elderly after graduation and the role of ageism attitude of students is investigated. With the results obtained in this study, the attitudes and perceptions of the students towards the elderly will be determined and suggestions will be made to the decision makers in the field of education and health management in order to help decreasing ageism attitude and motivate young people to work in elderly care. This study, which will contribute to the training of health technicians who will actively work in healthcare in the future, aims to be beneficial not only for the group, but also for all healthcare workers and the country's healthcare system.

\section{MATERIALS AND METHOD}

\section{Participants}

A descriptive and cross-sectional study was carried out in nine programs (Dental and Prosthetics Technology, Oral and Dental Health, Anesthesia, Dialysis, Medical Imaging Techniques, Medical Documentation, Orthosis and Prosthesis Techniques, Physiotherapy) of a Vocational Health School in a state university in Southeast of Turkey. The study was held online with $768(80 \%)$ participants studying in the $1^{\text {st }}$ and $2^{\text {nd }}$ classes in $2020-2021$ spring 
semester. Sample selection method wasn't applied in the study and it was aimed to reach the whole population. Approximately $20 \%$ of students were unable to take part in the study. Before the study, a written permission was received from the Directorate of Health School, and a verbal consent was obtained from the students. Research ethical approval was also received from the Medical Faculty Ethics Committee of Dicle University (232/ 09.04.2021).

Descriptive statistics of the participants' socio-demographic status, their family members' situation and interaction with an elderly person in family were inquired and the results are shown in Table 1.

Table 1. Descriptive Statistics of Demographics of Participants

\begin{tabular}{|l|l|l|l|l|l|}
\hline & $\mathbf{N}$ & $\mathbf{\%}$ & & $\mathbf{N}$ & $\mathbf{\%}$ \\
\hline Year in School & & & Sex & & \\
\hline 1 st & 345 & 49.0 & Female & 519 & 73.7 \\
\hline nd & 359 & 51.0 & Male & 185 & 26.3 \\
\hline Age & & & Residence & & \\
\hline $18-19$ & 316 & 44.9 & City & 471 & 66.9 \\
\hline $20-21$ & 258 & 36.6 & Town & 137 & 19.5 \\
\hline$>22$ & 130 & 18.5 & Village & 96 & 13.6 \\
\hline Household Income & & & & & \\
\hline Income less than expenses & 370 & 52.6 & Family Type & & \\
\hline Income equal to expenses & 274 & 38.9 & Immediate & 655 & 93.0 \\
\hline Income more than expenses & 60 & 8.5 & Extended/Other & 49 & 7.0 \\
\hline Education level of mother & & & Education level of father & & \\
\hline Primary school and below & 555 & 78.8 & Primary school and below & 284 & 40.3 \\
\hline Middle school & 80 & 11.4 & Middle school & 184 & 26.1 \\
\hline High School Diploma & 46 & 6.5 & High School Diploma & 153 & 21.7 \\
\hline College/University & 33 & 3.3 & College/University & 83 & 11.8 \\
\hline Employment of Mother & & & Employment of father & & \\
\hline Unemployed & 648 & 92.0 & Employed & 366 & 52.0 \\
\hline Employed & 37 & 5.3 & Temporarily unemployed & 262 & 37.2 \\
\hline Temporarily Unemployed & 19 & 2.7 & Unemployed & 76 & 10.3 \\
\hline $\begin{array}{l}\text { Do you have an elderly } \\
\text { relative? }\end{array}$ & & & $\begin{array}{l}\text { Have you ever lived with an } \\
\text { older adult? }\end{array}$ & & \\
\hline Yes & 662 & 94.2 & Yes & 217 & 30.8 \\
\hline No & 42 & 5.8 & No & 487 & 69.2 \\
\hline
\end{tabular}

It was determined that $73.7 \%$ of the vocational health school students were female, $44.9 \%$ were aged between $18-19$ years and $51 \%$ of them were students of $2^{\text {nd }}$ grade. Of the students, $66.9 \%$ were living in city and $93.0 \%$ had immediate family. While over $90.0 \%$ of mothers of the students were unemployed and had middle school diploma or lower education level, only $52.0 \%$ of fathers of them were employed. $94.2 \%$ of students had an elderly relative and only $30.8 \%$ of them declared that they had lived with an elderly before.

\section{Measures}


In the study, Ageism Attitude Scale (AAS) developed by Y1lmaz and Terzioğlu (2011) was used for data collection. The first section of the questionnaire included questions to determine the demographics of the students. The second section of the questionnaire consisted of a 23item scale measuring students' attitudes toward ageism and consisted of three dimensions as Restricting Life of Elderly, Positive Ageism and Negative Ageism. The items used in the research model were measured by five-point Likert Scale. There are positive and negative attitude statements in the scale. Positive attitude statements are graded as $5=$ Strongly Agree, 4= Agree, 3= Undecided, 2= Disagree, 1= Strongly Disagree. Answers given for negative attitudes were reverse-coded. After examination of Cronbach's alpha test, descriptive statistics were applied. Shapiro-Wilk and Colmogorov-Smirnov Normality tests were carried out to test the normality. With the help of SPSS 21 program, statistical tests were evaluated via one-way ANOVA test, Scheffe test, Pearson correlation test, t-tests and Chi-squared test were evaluated.

\section{FINDINGS}

Of 768 questionnaires, 704 were suitable for the statistical analysis. Because of Covid 19 Pandemic some students were having difficulties in accessing internet or listening to the lessons. Thus, the survey was done with active students who were following the lessons regularly. Reliability of the scale was checked with the help of Cronbach's alpha test. Cronbach's alpha value for total Ageism Attitude Scale was 0.805, where it was 0.821 for Positive Ageism dimension; 0.686 for Negative Ageism and 0.719 for Restricting Life of Elderly dimension. In order to use parametric statistical tests, normality of the distribution was tested and Shapiro-Wilk test statistics was calculated as $0.996(\mathrm{p}=0.057)$ and KolmogorovSmirnov Test statistics were calculated as $0.023(\mathrm{p}=0.200)$. The results of these tests should be non-significant to verify the normality of the distribution. As the distribution of AAS scores were normal, parametric tests could be applied to the data set.

Mean, Standard deviation and Cronbach's alpha values of items and dimensions of Ageism Attitude Scale can be seen in Table 2. Answers given to negative questions have been reversecoded.

Table 2. Mean, SD and Cronbach Values of Items and Dimensions of Ageism Attitude Scale

\begin{tabular}{|l|l|l|l|}
\hline Dimensions & \multicolumn{1}{|c|}{ Mean } & SD & Cronbach \\
\hline Restricting Life Of Elderly & & $\mathbf{0 . 7 1 9}$ \\
\hline 1. The external appearance of the elderly is repulsive. & 4.707 & 0.519 & \\
\hline $\begin{array}{l}\text { 2. Care of the elderly should not be considered to be an economic } \\
\text { burden by family members. }\end{array}$ & 4.322 & 0.701 & \\
\hline
\end{tabular}




\begin{tabular}{|l|l|l|l|}
\hline 3. Elderly people can't carry bags and packages without help. & 4.183 & 1.024 & \\
\hline $\begin{array}{l}\text { 4. It is unnecessary for the elderly to buy homes, cars, possessions } \\
\text { or clothes. }\end{array}$ & 4.491 & 0.631 & \\
\hline 5. The elderly should live in homes for the elderly. & 4.434 & 0.662 & \\
\hline 6. Lives of the elderly should be limited to their homes. & 4.612 & 0.548 & \\
\hline $\begin{array}{l}\text { 7. Elderly people should be paid less than young people in their work } \\
\text { lives. }\end{array}$ & 4.252 & 0.881 & \\
\hline $\begin{array}{l}\text { 8. Preference should be given to care for young people over the } \\
\text { elderly in the hospital. }\end{array}$ & 4.183 & 1.024 & \\
\hline 9. Elderly people who lose their spouses should not remarry. & 3.938 & 1.031 & \\
\hline Positive Ageism & & $\mathbf{0 . 8 2 1}$ \\
\hline 10. Elderly people are more tolerant than young people. & 4.156 & 0.830 & \\
\hline 11. Elderly people are more compassionate. & 3.796 & 1.070 & \\
\hline $\begin{array}{l}\text { 12. When decisions are made in the family the opinions of the elders } \\
\text { should be considered. }\end{array}$ & 4.399 & 0.692 & \\
\hline $\begin{array}{l}\text { 13. The elderly should be shown importance by the family members } \\
\text { with whom they live. }\end{array}$ & 3.805 & 1.006 & \\
\hline 14. Elderly people are more patient than young people. & 3.513 & 1.255 & \\
\hline $\begin{array}{l}\text { 15. Young people should learn from the experiences of elderly } \\
\text { people. }\end{array}$ & 4.383 & 0.702 & \\
\hline $\begin{array}{l}\text { 16. When the family budget is being developed the opinions of the } \\
\text { elderly should be sought. }\end{array}$ & 4.231 & 0.777 & \\
\hline $\begin{array}{l}\text { 17. Preference should be given to the elderly in places where waiting } \\
\text { in line is required. }\end{array}$ & 4.603 & 0.624 & $\mathbf{0 . 6 8 6}$ \\
\hline Negative Ageism & & 1.210 & \\
\hline $\begin{array}{l}\text { 18. Preference should be given to young people for promotions in } \\
\text { work situations. }\end{array}$ & 3.214 & 1.161 & \\
\hline $\begin{array}{l}\text { 19. Preference should be given to young people over the elderly for } \\
\text { hiring for jobs. }\end{array}$ & 2.974 & 0.920 & \\
\hline $\begin{array}{l}\text { 20. Elderly people are not able to adapt to changes like young } \\
\text { people. }\end{array}$ & 2.823 & 3.484 & $\mathbf{0 . 8 0 8}$ \\
\hline 21. Elderly people are always ill. & 2.990 & $\mathbf{6 0}$ & \\
\hline 22. Elderly people should not go outside on their own. & 3.718 & 0.932 & \\
\hline $\begin{array}{l}\text { 23. The basic responsibility for the elderly is housework and kitchen } \\
\text { chores and care of their grandchildren. }\end{array}$ & $\mathbf{3 . 9 6 1}$ & $\mathbf{0 . 4 3 0}$ & \\
\hline Total AAS Mean and SD (Min: 2.81; Max: 5.00) & 91 & \\
\hline Total AAS (Min:45; Max115) & & \\
\hline \\
\hline
\end{tabular}

Y1lmaz and Terzioğlu (2011) who developed the Ageism Attitude Scale found AAS scores as 86 (Min: 45; Max: 115) in their study. In this study, AAS score was found as 91 (Min: 45; Max: 115). This value is greater than Y1lmaz and Terzioğlu's result. The mean of the all AAS scale was $3.961 \pm 0.430$. When the mean scores of items were looked into, it was seen that least AAS mean scores were in hiring of elderly and being active in business. It may rise because of the high unemployment rates in young individuals.

When the impact of demographics on Ageism Attitude Scale scores of the students were considered, there were no statistically significant differences between AAS scores in age 
$(\mathrm{F}=1.847 ; \mathrm{p}>0.05)$, year in school $(\mathrm{t}=-0.179 ; \mathrm{p}>0.05)$, sex $(\mathrm{t}=1.531 ; \mathrm{p}>0.05)$, residence $(\mathrm{F}=0.847 ; \mathrm{p}>0.05)$, income $(\mathrm{F}=0.110 ; \mathrm{p}>0.05)$ and family type $(\mathrm{F}=0.380 ; \mathrm{p}>0.05)$. An important finding of this study was mothers' education level affects AAS score means of the participants. Based on the ANOVA and Scheffe tests, there was a significant difference between AAS scores of students whose mothers' were primary school and high school graduates $(\mathrm{F}=3.749 ; \mathrm{p}<0.05)$. Students whose mothers' educational level is high had higher AAS scores. There were no other significant differences between AAS scores of students in their fathers' education and employment status of mothers and fathers.

Some research questions as "Do you have an elderly relative?", "Have you ever lived with an elderly?" were asked to students (Table 1). AAS score means of students weren't significantly different between the groups who had an elderly relative or not $(\mathrm{t}=0.876 ; \mathrm{p}>0.05)$. The participants who lived with an elderly didn't have statistically different AAS scores from the other group ( $\mathrm{t}=1.203 ; \mathrm{p}>0.05)$. There was an important factor affecting intention to live (or not) with an elderly in the future. Students who lived with an elderly in the past were less likely to live with an older adult in the future $\left(\chi^{2}=23.341 ; \mathrm{p}<0.001\right)$.

In this study also the research questions "Do you want to live with an older adult in the future?" and "Do you want to work in elderly care after graduation?" were asked to participants and impact of demographics on willingness to live with an elderly and to work in elderly care in the future were considered (Figure 1).

Figure 1. Willingness of Participants to Live with an Elderly and Work in Elderly Care in

The Future

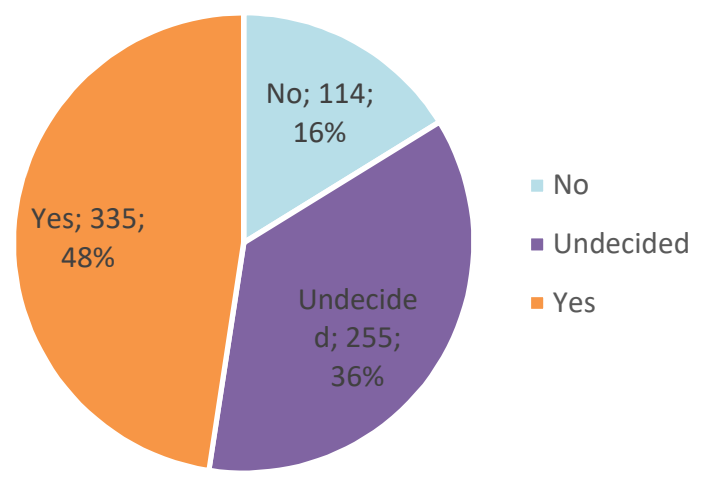

Do you want to live with an elderly in the future $(\mathrm{N} ; \%)$ ?

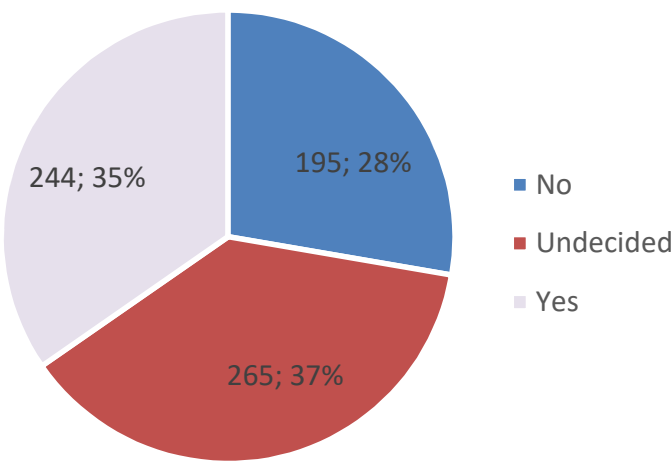

Do you want to work in elderly care after graduation $(\mathrm{N} ; \%)$ ? 
As can be seen from Figure 1 while $35 \%$ of students want to work in elderly care after graduation, $37 \%$ of them are undecided and $28 \%$ of them don't want to work in elderly care. Additionally, while $48 \%$ of them want to live with an elderly, $36 \%$ of them are undecided and $16 \%$ of them don't want to live with an elderly in the future. One-way Anova, Scheffe and ChiSquared tests were used to determine the relationship between demographics and willingness to work in elderly care and living with an older adult in the future. According to the results of the study, students who have less income are likely to have more willingness to work in elderly care $(\mathrm{F}=14.735 ; \mathrm{p}<0.001)$. According to Scheffe test results, there was a significant difference between the lowest and the highest income groups. There were no other significant differences between demographic groups in willingness to work in elderly care after graduation. On the other hand, there are some important factors affecting willingness to work in elderly care. Of the students, those who had higher Ageism Attitude Scale scores and positive attitude towards older adults were more willing to work in elderly care. Based on the ANOVA and Scheffe tests there was a significant difference between Ageism Attitude Scale scores of students among all groups $(\mathrm{F}=17.435 ; \mathrm{p}<0.001)$. Additionally, students having higher AAS scores were more likely to live with an elder adult in the future $(\mathrm{F}=37.772 ; \mathrm{p}<0.001)$.

The effect of the experience of students regarding their visiting to a nursing home on ageism attitude and willingness to work in elderly care was investigated. Thus a question "Have you ever visited a nursing home?" was asked to participants (Figure 2). Also in order to investigate young participants" perception of old age and its role on ageism attitude "What age do you consider old?" was asked in the questionnaire (Figure 2).

Figure 2. Nursing Home Visit and Perception of Old Age Among Participants

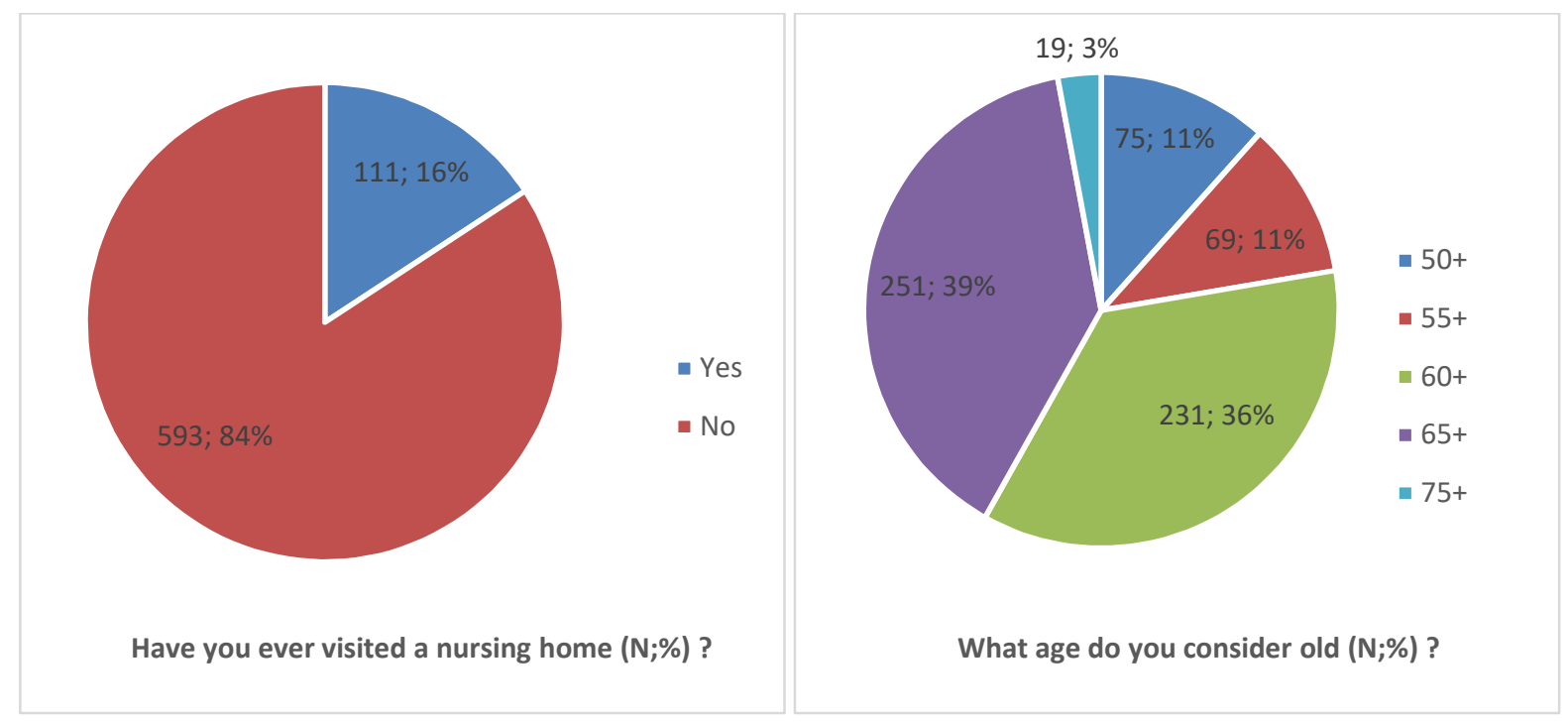


According to the results of the study $16 \%$ of the students visited a nursing home. Based on oneway ANOVA and Scheffe tests, visiting a nursing home has a positively significant effect on willingness to work in elderly care $\left(\chi^{2}=8.709 ; p<0.05\right)$ but it did not on intention to live with an elderly in the future $\left(\chi^{2}=3.442 ; \mathrm{p}>0.05\right)$. Although visiting a nursing home affected the students' willingness to work in elderly care, it doesn't affect mean of AAS scores of the participants $(\mathrm{t}=1.042 ; \mathrm{p}>0.05)$.

When the research question was asked to student as "What age do you consider old?" it was found that only $45 \%$ of them defined 65 age and over old. On the other hand, $55 \%$ of them defined 55-65 years of old adults as the elderly. Based on the ANOVA and Scheffe test results, there were statistically significant differences in Ageism Attitude Scale score means between groups defining older age in different levels. AAS mean scores of the students defining old age as over 55 were significantly different from the ones who defined old age as 65 and over $(\mathrm{F}=6.556 ; \mathrm{p}<0.001)$. Students who thought 55 and over to be old-age had lower scores of AAS scale.

\section{DISCUSSION}

In the study ageism attitude towards elderly found to be related with health school students' willingness to work in the elderly care. This result is consistent with many studies available in the literature. Hweidi and Al-Obeistat (2006) found that Jordanian nursing students who prefer to work with elderly after graduation reported more positive attitudes towards elderly than students who did not. Also Türgay et al. (2015), Turan et al. (2016) and Wang et al.(2009) found significant relationship between willingness for working in geriatric medicine and positive attitudes towards elderly in their study conducted by different health sciences students. Effect of gender on ageism has been investigated in many studies. Some research has found female students' ageism attitude scores and willingness to work in the elderly care higher. In their study investigating attitudes of medical students in Singapore towards older people and willing to consider a career in geriatric medicine, Chua et al.(2008) investigated that female students were more willing and had higher attitude scores. Based on the literature, higher ageism attitudes scores were declared in some research conducted in different groups of people (Bodner et al., 2012; Bergman et al., 2013; Randler et al.,2016; Ben-Harush et al.). Also Daba and Kesen (2015) and Güven et al.(2012) indicated that female students from different schools adopted more positive attitudes towards elderly . On the other hand, more negative attitudes of female nursing students were reported by Köse et al. (2015), Şahin and Erdem (2017) and Hweidi and Al-Obesitat (2006). In this study, gender differences were not statistically 
significant in attitudes about ageism. This finding is compatible with some other researchers' results (Demir et al.,2016; Ünsar et al.,2015). According to our results, like most of demographics, gender doesn't play a role on ageism attitude of the health school students. All male and female students have positive attitude scores.

Although in this study no significant relationship was found between age or class of students and ageism attitude scores, Daba and Kesen (2015) and Köse et al.(2015) found that older aged and senior class students were more likely to have lower ageism attitude scores. On the other hand, while Hweidi and Al-Obeistat (2006) and Turan et al. (2016) reported that first year students had more favorable attitudes than senior students. Although there are different results regarding age and class of the students, in this study, it was found that in all age groups and classes students have higher positive attitude scores towards elderly.

Influence of education of parents of students on ageism attitude was investigated by some researchers. While in the study that investigating nursing students' attitudes toward ageism, Y1lmaz and Özkan (2010) and Turan et al. (2016) reported higher attitude scores in student groups whose parents have lower education, some researchers found no relationship between family structure, education levels of parents and ageism attitude scores (Y 1lmaz \& Terzioğlu, 2011; Köse et al., 2015). This is a conflict with this study as there was a significant difference between AAS scores of student groups whose mothers' educational level was primary school and high school. Students whose mothers' educational level was high had higher AAS scores. Another finding of this study is that students who have less income are likely to have more willingness to work in elderly care. This finding is compatible with some studies (Köse et al., 2015; Usta et al.,2012). On the other hand, Turan et al. (2016) reported that students having extended families had higher attitude scores. In this study, there wasn't a relationship between family type and students' AAS scores.

Based on the literature, attitude of students who lived with an elderly were lower than those who did not live with an older adult (Wang et al., 2009, Turan et al., 2016). This finding is compatible with this study. Maybe due to the bad experiences they lived in their homes, this group has a lower attitude score. In the study, it was found that students who had visited a nursing home were more willing to work in the elderly care after graduation. Based on the literature, educational and experimental intervention affected students' willingness to work in elderly care positively (Ryan et al., 2007; Gholamzadeh et al., 2018). It is clear that students who have not experienced elderly care in a nursing home or seen the elderly living there have more negative thoughts. Nursing home visits or training programs should encourage students 
to work in elderly care. Based on the literature, training progress regarding geriatric skills has a significant impact on students' attitudes scores (Ryan et al., 2007; Gholamzadeh et al., 2018; Zhao et al.,2020).

\section{CONCLUSION}

When the results of our study are analyzed, it will be seen that the young generation generally has a positive attitude towards the elderly, but the majority of them are indecisive or distant about working in the field of elderly care in the future. We need to encourage young people to work in this field, which presents great opportunities both at home and abroad in terms of future job prospects. Just as in the whole world, the elderly population is increasing in our country. With the increasing elderly population, issues related to the care and health of elderly people are gaining more importance (Gümüş \&Sarıbaş, 2016). Compared to developed countries, elderly individuals in our country are still valued more by the younger generations and their families due to the low ratio of the population and the traditional family structure, and the elderly are cared for in their own homes or by their families instead of care homes and nursing homes. However, both the low number of children and the changing and increased role of women in work life show that there will be some problems in the care of the elderly in our country in the future. In such a case, the importance of the labor force that will work actively in the care of the elderly will increase even more.

The qualitative and quantitative quality of the personnel who will work in the elderly care services will play an important role in the elderly population to spend their final years comfortably (Gümüş \& Şahin, 2016). Even if the majority of students currently studying in healthcare educational institutions do not work in care of the elderly, they will have to serve older individuals to a greater extent than today. As a member of an army of healthcare providers, current students of Healthcare Services Vocational Schools will play an active role in the care of the elderly in our country that will have an ever aging population in the future. Therefore, although the attitude towards the elderly is important for all segments of the society, it is much more important for the personnel who will work in healthcare.

The need for healthcare personnel and other personnel, which is needed in the care of the elderly and is expected to increase over the years, is tried to be compensated and met at different levels in our country. However, it cannot be said that young people are very enthusiastic about working in the care of the elderly, as demonstrated in our study. According to the studies carried out by many researchers both in our country and in the world, young people have placed the care of the elderly in the last place in their job preference rankings. In these studies, it has been 
seen that in addition to the psychological and physical difficulties of the job itself, the lack of opportunities in elderly care and the low quality of care also affect the preferences of the caregivers. That's why we need to encourage young people to receive education in the care of the elderly with the right government policies. The lack of clarity of job descriptions and the lack of job opportunities, hiring people having elderly care program certificates are among the reasons that increase this hopelessness.

Studies conducted with students in the field of health have shown that students stay away from working in elderly care in the future. Elderly care is not just healthcare for them. Elderly care specialists will be needed in the future, even for issues such as managing the economic situation of the elderly, shopping, arranging their social lives, and arranging their medical appointments. Considering the job opportunities and demand in services concerning the care of the elderly, it can be said that there is no need for experts in many subjects today. However, the children of the group that will be over 70 years old in 10 years may still be in business life. Increasing the retirement age and the ascending role of women in business life and the decrease in the number of children show that the care of the elderly will be left to specialists. If we include the regularly increasing proportion of the elderly population, the need for elderly care specialists arises. Population projections should be taken into account in our country's long-term plans regarding elderly care, and preparations should be made in advance for the conditions that will occur as a result of the economic and social transformations that the country undergoes.

Our study has shown that there is a positive relationship between the low ratio of ageism among young people and the tendency to work in the field of elderly care in the future. In order to encourage young people to work in this field, their concerns should be addressed. Education starts in the family; in our study too, it was observed that students whose mothers had a high educational level had more positive feelings and attitudes towards the elderly. Therefore, families should approach this subject with more sensitivity while raising their children. A second important finding of this study is that students' visit to an institution serving in the field of elderly care and their communication or contact with the elderly produce favorable effects on their attitudes towards the elderly. At health vocational schools, not only students enrolled in the elderly care program, but students of all programs should, at any time within their study period, visit the institutions giving one-to-one care to the elderly. Furthermore, in this study, it has also been observed that students stay aloof of the elderly care, a subject they are not familiar with, therefore, it should be taught to students, by incorporating into the syllabus if required, that elderly care not only encompasses the care given to the sick and the disabled, but it is, in 
fact, a broad area covering all needs of the elderly. Finally, both as part of a state policy and in terms of employment volume, students of universities' health vocational schools should be encouraged to pursue a career in elderly care after their graduation.

Conflict of interest: The author declares that she has no conflict of interest.

Financial disclosure: There are no financial supports

Ethical Approval: The study was approved by Dicle University Medical Faculty Ethics Committee for Noninterventional Studies 232/09.04.2021

\section{REFERENCES}

Adıbelli, D., Türkoğlu, N, \&Kılıç, D. (2013). Öğrenci hemşirelerin yaşlılığa ilişkin görüşleri ve yaşlılığa karşı tutumları. Dokuz Eylül Üniversitesi hemşirelik Yüksekokulu Elektronik Dergisi, 6(1), 1-8

Altay, B. \& Aydın, T. (2015). Hemşirelik öğrencilerinin yaşlı ayrımcılığına ilişkin tutumlarının değerlendirilmesi. Hemşirelikte Eğitim ve Araştırma Dergisi, 12(19), 11-18.

Ben-Harush, A., Shiovitz-Ezra, S. \& Doro, I. (2017). Ageism among physicians, nurses, and social workers: findings from a qualitative study. European journal of ageing, 14(1), 3948 .

Bergman, Y.S., Bodner, E. \& Cohen-Fridel, S.(2013). Cross-cultural ageism: Ageism and attitudes toward aging among Jews and Arabs in Israel. International Psychogeriatrics, 25(1), 6-15.

Bleijenberg, N., Jansen, M., \& Schuurmans, M. (2012). Dutch nursing students' knowledge and attitudes toward older people - a longitudinal cohort study. Journal of Nursing Education and Practice, 2, 1-8.

Bodner, E., Bergman, Y. S. \& Cohen-Fridel, S. (2012). Different dimensions of ageist attitudes among menand women: a multigenerational perspective. International Psychogeriatrics, 24(6), 895-901.

Butler, R.N. (1980). Ageism: A foreword. Journal of Social Issue,36, 8-11. https://doi.org/10.1111/j.1540-4560.1980.tb02018.x

Chua, M.P., Tan, C.H., \& Merchant, R.(2008). Attitudes of first year medical students in Singapore towards older people and willingness to consider a career in geriatric medicine. Ann Acad Med Singapore,37, 947-51.

Daba, S. \& Kesen, N.F.(2015). Attitudes of social work students towards the ageism. The Journal of International Social Research, 8(38), 702-710.

Demir, G., Bicer, S. \& Bulucu, G.D., (2016). Attitudes of nursing students about ageism and the related factors. $J$ Caring Sci.,9, 900-8.

Duyan, G.Ç., Tuncay, T., Özdemir, B. \&Duyan, V. (2016). Attitudes of Social Work Students Towards Old Age, European J of Social Work, 19(5), 764-778. 
Erol, S., Pınar, R., Gür, K., Ergün, A., \&Hayran, O. (2013). Attitudes towards old people among Turkish university students. IFA and TURYAK International Istanbul Initiative on Ageing "International Solidaritiy", Turkey, 2013

Fraboni, M., Saltstone, R. \& Hughes, S. (1990). The Fraboni Scale of Ageism (FSA): An attempt at a more precise measure of ageism. Can J Ageing.9, 56-66.

Gholamzadeh, S., Khastavaneh, M. \& Khademian, Z. (2018). The effects of empathy skills training on nursing students' empathy and attitudes toward elderly people. BMC Med Educ, 18 , 2-7. https://doi.org/10.1186/s12909-018-1297-9

Gümüş, R. \& Şahin, A. (2016). Utilization of health services by the elderly in Turkey between 2008 and 2012: Analysis of Turkstat Health Surveys. Düzce Üniversitesi Sağllk Bilimleri Enstitüsü Dergisi, 43(4), 74-78.

Gümüş, R. \& Sarıbaş, S. (2016). Utilization of Home Health Care Services Provided by Government Among Elderly Individuals Between 2010 and 2015 in Diyarbakır, Turkey.Turkish J of Geriatrics, 19(39), 189-194.

Güven, Ş., Muz, G.U. \& Ertürk, N.E. (2012). Üniversite öğrencilerinin yaşlı ayrımcılığına ilişskin tutumları ve bu tutumların bazı değişkenlerle ilişkisi. Anadolu Hemşirelik ve Sağlık Bilimleri Dergisi, 15(2),99-105.

Hughes, N.J., Soiza, R.L., Chua, M. \& Hoyle, G.E. (2008). Medical student attitudes toward older people and willingness to consider a career in geriatric medicine. J Am Geriatr Soc., 56(2), 334-38.

Hweidi, I.M. \& Al-Obeisat, S.M. (2006). Jordanian nursing students' attitudes toward the elderly. Nurse Educ. Today, 26 (1), 23-30. http://dx.doi.org/10.1016/j.nedt.2005.0

Karadă̆, E., İnkaya B.V. \& Karatay, G. (2012) Hemşirelik Öğrencilerinin Yaşlı Ayrımcılığına İlişkin Tutumları, Ege Üniversitesi Hemşirelik Fakültesi Dergisi, 28(2), 31-40

Kizilci, S., Küçükgüçlü, Ö. Mert, H. \&Soylemez, B.A. (2013). Examination of Nursing Students' Attitudes Towards Older People in Turkey. Health Medicine, 7, 544-552.

Kogan, N. (1961). Attitudes towards old people the development of a scale and an examination of correlates. J Abnorm Soc Psychol. 62, 44-54.

Köse, G., Ayhan \& H., Taştan, S. (2015). Determination of the attitudes of students from a different department in the field of health on the discrimination against the elders. Gulhane Med J.,57,145-51.

Kulakçı, H. (2010). Hemşirelik Lisans Programında Birinci ve Dördüncü Sınıf Öğrencilerinin Yaşl1lık ve Yaşlanmaya İlişkin Düşüncelerinin ve Görüşlerinin Değerlendirilmesi. Dokuz Eylül Üniversitesi hemşirelik Yüksekokulu Elektronik Dergisi, 3(1), 15-22

Lasher, K.P. \& Faulkender, P.J. (1993). Measurement of ageing anxiety: Development of the anxiety about ageing scale. Int J Ageing Hum Dev., 37(4), 247-60.

Özdemir, Ö., Bilgili, N. (2016). Attitudes of Turkish Nursing Students Related to Ageism. Journal of Nursing Research, 24(3), 211-6 
Ozkaptan, B. B., Altay, B., \& Cabar, H. D. (2012). Attitudes of nursing students towards older people in Turkey. Health Medicine, 6, 3351-3358.

Palmore, E.B. (1999). Ageism: Negative and Positive. Springer Publishing Company, New York; 3-86.

Randler C, Vollmer C. \& Wilhelm D. (2014). Attitudes towards the elderly among German adolescents. Educational Gerontology, 40(3), 230-238.

Rosencrantz, H.A. \& McNevin, T.E. (1969). A factor analysis of attitudes toward the aged, Gerontologist, 9 , 55-9.

Ryan, A., Melby, V. \& Mitchell L. (2007). An evaluation of the effectiveness of an educational and experiential intervention on nursing students' attitudes towards older people. International Journal of Older People, Nursing, 2(2), 93-101.

Şahin, H. \& Erdem Y. (2017) .Determining the attitudes of nursing students toward the elderly. Turkish J Soc Res., 1, 219-32.

Soyuer, F., Ünalan, D., Güleser, N., \& Elmalı, F. (2010). The attitudes of health vocational school students towards ageism and the relation of these attitudes with some demographical variables. Mersin University Health and Science Journal, 3, 20-25.

Tuik, İstatistiklerle Yaşlılar (2021). Ankara: TUIK [Cited 2021 June 29]. Avaliable from: https://data.tuik.gov.tr/Bulten/Index?p=Istatistiklerle-Yaslilar-2019-33712

Turan, E., Yanardag \& M., Metintas, S. (2016). Attitudes of students of health sciences towards the older persons. Nurse Education Today,36, 53-7.

Türgay, A.S., Şahin, S. \& Aykar, F.Ş. (2015). Attitudes of Turkish nursing students toward elderly people. European Geriatric Medicine, 6, 267-70.

Ünsar, S., Erol, Ö. \& Kurt, S. (2015). Evaluation of ageism attitudes of nursing students. Cumhuriyet Nurs. J.,4,61-7.

Usta, Y.Y., Demir, Y., \& Yönder, M., (2012). Nursing students' attitudes toward ageism in Turkey. Archives of Gerontology and Geriatrics,54(1), 90-93.

Wang, C., Liao, W. \& Kao, M. (2009). Taiwanese medical and nursing student interest levels in and attitudes towards geriatrics. Annals Academy of Medicine, 38, 230-36.

Y1lmaz, E. \& Özkan, S. (2010). Attitudes of nursing students towards ageism. e-J Nurs Sci Art.,3,35-53.v

Yı1maz, E., \& Özkan, S. (2010). Hemşirelik öğrencilerinin yaşlı ayrımcılığına ilişkin tutumları, Maltepe University Nursing Science and Art Journal, 3 (2), 35-53

Y1lmaz, M.Ç. \& İnce, F.Z. (2017). Relationship between nursing and elderly care students' attitudes towards ageism, Belitung Nursing Journal, 3(4), 281-296.

Y1lmaz, V.D. \& Terzioğlu, F. (2011). Development and psychometric evaluation of ageism attitude scale among the university students. Turkish Journal of Geriatrics. 14(3), 25968. 
Zhao, H., Wu, B., Shi, J., Reifsnider, E. \& Fan, J. (2020). Chinese Medical Students' Attitudes toward Older Adults and Willingness To Consider a Career in Geriatric Medicine: A Cross-Sectional Survey, Teaching and Learning in Medicine,32(5), 486-93. Doi: 10.1080/10401334. 